\title{
Partnerdoding in Nederland
}

Marieke Liem, Inge de Jong \& Jade van Maanen

Partnerdoding is één van de meest voorkomende vormen van moord. Het doel van dit onderzoek is het in kaart brengen van de aard en omvang van partnerdoding in Nederland in de periode 2009-2014, waarbij gebruik is gemaakt van politiedata, rechtbankdossiers en nieuwsartikelen. Uit dit onderzoek blijkt dat partnerdoding 29 keer per jaar voorkomt, met een slachtofferratio van 0,20 per 100.000. Dit is vergelijkbaar met andere West-Europese landen. Daarnaast heeft de afgelopen jaren een relatieve daling van partnerdoding plaatsgevonden. Partnerdodingen betreffen grotendeels mannelijke daders en vrouwelijke slachtoffers in heteroseksuele relaties, uitgevoerd met een steek- of snijwapen. Afsluitend reflecteren we op oorzaken voor de relatieve daling van partnerdoding.

\section{Introductie}

Sinds het begin van deze eeuw is het moordcijfer in Nederland dalende. Waar in de jaren negentig gemiddeld 1,57 moordslachtoffers per 100.000 inwoners vielen te betreuren, liep dit terug tot 0,94 in de afgelopen jaren (2009-2014) (Liem \& Leissner, 2016). Eén van de meest voorkomende typen dodingen betreft het doden van een partner. Het is echter de vraag in hoeverre partnerdoding in Nederland een vergelijkbare dalende trend laat zien en in welke mate de verklaringen daarvoor gekoppeld kunnen worden aan de algehele daling van het moordcijfer.

Het fenomeen partnerdoding is zo oud als de mensheid (Block \& Christakos, 1995). Zo kent de Griekse mythologie het verhaal van Heracles, die onder de invloed van betovering zijn vrouw Megara en hun kinderen doodde door hen in het vuur te gooien. Vele eeuwen later beschreef Shakespeare in Othello hoe de gelijknamige hoofdpersoon zijn geliefde Desdemona doodde uit de overtuiging dat zij hem bedroog. Hieruit afgeleid staat jaloersheidswaan, ook wel pathologische jaloezie genoemd, bekend als het 'Othello-syndroom'. Hoewel in de historische voorbeelden van Othello en Heracles partnerdoding plaatsvond tussen mannelijke daders en hun vrouwen, omvat partnerdoding zowel huidige als voormalige partners (Swatt \& He, 2006) en zowel heteroseksuele als homoseksuele partners (Breiding e.a., 2015). In dit artikel beschouwen we een partner als iemand met wie de dader een intieme persoonlijke relatie heeft of heeft gehad, gekarakteriseerd door emotionele verbondenheid, zich uitende in fysiek en/of seksueel contact (Breiding e.a., 2015).

Tot op heden bestaat er geen uniform overzicht van de trends, aard en omvang van partnerdoding in Nederland. Dit is mede toe te schrijven aan een gebrek aan een centraal orgaan die dergelijke dodingen onderzoekt en registreert. Dit artikel beoogt deze lacune te vullen door een gedetailleerde analyse op zaak-, slachtoffer- 
en daderniveau weer te geven van partnerdoding in Nederland. Tevens onderzoeken we in hoeverre de omvang van partnerdoding gelijke tred houdt met de dalende trend van het totale moordcijfer en hoe we deze trend kunnen verklaren.

\section{Theoretische achtergrond}

Om de aard en omvang van dit fenomeen nader te duiden, bespreken we hier kort twee clusters van theorieën, te weten (a) macro-sociologische theorieën die langetermijntrends in levensdelicten trachten te verklaren, en (b) theorieën die vanuit psychologisch en sociologisch perspectief specifiek een verklaring bieden voor partnerdodingen.

\subsection{Trends in levensdelicten}

In de eerste plaats kan de algemene daling in levensdelicten beschouwd worden als voortzetting van de trend in geweldscriminaliteit die zich al vijfhonderd jaar voortzet (Eisner, 2003). Historische studies naar levensdelicten in Nederland lieten bijvoorbeeld zien, dat deze delicten door de eeuwen heen in frequentie afnamen, met een scherpe afname tussen de zestiende en achttiende eeuw in de vroegmoderne periode (Spierenburg, 2008). Zo beargumenteert Elias (1978) in zijn civilisatietheorie dat naarmate westerse samenlevingen steeds geciviliseerder worden (met een 'civilisatieversnelling' in de vroegmoderne tijd), er van burgers een steeds grotere mate van zelfcontrole wordt verlangd. De langdurige daling van fataal geweld houdt zo min of meer gelijke tred met de voortschrijdende beschaving van samenlevingen (Eisner, 2003). In deze zin is de recente daling in levensdelicten in Nederland niet meer dan een onderdeel van een langetermijntrend en zou deze niet apart geproblematiseerd hoeven te worden (Weerman e.a., 2011). In dit licht bezien vormen man-tot-vrouwdodingen zoals partnerdodingen een type doding die onderhevig is aan dezelfde dynamiek als andere dodingen, zoals man-tot-mandodingen.

Deze hypothese wordt tegengesproken door de Finse criminoloog en socioloog Veli Verkko (1951), die een tweetal wetten formuleerde op basis waarvan de omvang en fluctuatie in levensdelicten te verklaren waren. In deze twee wetten staat de rol van geslacht centraal. Zo stelt hij in zijn statische wet, dat mannen veruit de meeste slachtoffers van levensdelicten vormen. Wanneer de moordratio hoog is, is het aandeel vrouwelijke slachtoffers laag, terwijl met een lage moordratio het aandeel vrouwelijke slachtoffers relatief hoog is. Zijn dynamische wet houdt in, dat wanneer de moordratio toeneemt, deze toename vooral het resultaat is van een stijging in man-tot-mandodingen, terwijl man-tot-vrouwdodingen en vrouw-tot-mandodingen relatief stabiel blijven. Volgens Verkko dienen redenen voor (verschuivingen in) de omvang van levensdelicten daarom ook gezocht te worden in veranderingen van man-tot-mandodingen. De ratio man-tot-vrouwdodingen, zoals veruit de meeste partnerdodingen, blijven volgens Verkko dus relatief stabiel over de tijd heen, in vergelijking met andere typen (met name man-tot-man) dodingen. 


\subsection{Partnerdoding}

In de partnerdoding-literatuur staan twee theoretische benaderingen centraal, die ieder een kant van dezelfde medaille vormen, te weten de vanuit feministische hoek ingegeven patriarchale theorie en de zelfbeschermingstheorie. Beide benaderingen zien partnerdoding in de context van een door mannen gedomineerde maatschappij. De eerstgenoemde theorie, tevens onderbouwd door psycho-evolutionaire benaderingen (zie bijv. Daly \& Wilson, 1988), dient vooral om partnerdodingen door mannen te verklaren, terwijl de zelfbeschermingstheorie dient om fataal geweld door vrouwen te verklaren.

Volgens de patriarchale theorie kan (fataal) geweld tegen vrouwen beschouwd worden in de context van een patriarchale samenleving. In een dergelijke samenleving zullen diegenen met de macht - mannen - diegenen zonder macht - vrouwen - controleren door geweld uit te oefenen, om te voorkomen dat hun dominante positie bedreigd wordt (Tracy, 2007). Eerdere reviewstudies lieten zien dat huiselijk geweld en partnerdoding sterk gerelateerd zijn (Garcia e.a., 2007; Kivisto, 2015). Zo werd in Amerikaans onderzoek gevonden dat eerder huiselijk geweld het risico op partnerdoding aanzienlijk liet toenemen (Bailey e.a., 1997). Vanuit dit patriarchale perspectief wordt partnerdoding bezien als een fatale uitkomst van de poging van de mannelijke dader om controle te behouden over zijn vrouwelijke partner. Deze theoretische benadering dient tevens te verklaren waarom mannen de voornaamste daders zijn van partnerdoding en vrouwen de meest voorkomende slachtoffers (Goussinsky \& Yassour-Borochowitz, 2012). Het risico op fataal geweld is het grootst wanneer de mannelijke dader de controle over zijn vrouwelijke partner dreigt te verliezen. De internationale literatuur wijst dan ook uit dat (dreiging tot) verlating, bijvoorbeeld in de vorm van een echtscheiding, de meest voorkomende aanleiding voor partnerdodingen is (Block \& Christakos, 1995; Campbell e.a., 2007; Garcia e.a., 2007).

Partnerdoding door vrouwen wordt voornamelijk verklaard door de zelfverdedigingstheorie. Evenals de patriarchale benadering, stelt de zelfverdedigingstheorie dat vrouwen door mannen gecontroleerd en gedomineerd worden. Vrouwen zouden slechts overgaan tot partnerdoding uit noodweer, waarbij zij geweld gebruiken om zichzelf en/of de kinderen te beschermen tegen hun mannelijke partner (Reckdenwald \& Parker, 2012). In dergelijke zaken is er veelal sprake van langdurig geweld, waarin een sociaal geïsoleerde vrouw (Eriksson \& Mazerolle, 2013) - al dan niet in combinatie met kinderen - fysiek wordt mishandeld en haar partner doodt in een ultieme poging te ontsnappen aan de gewelddadige relatie (Serrana \& Firestone, 2004). In dergelijke gevallen wordt niet zelden gesproken van een 'battered woman syndrome' (BWS), ofwel een combinatie van aangeleerde hulpeloosheid en het herhalende karakter van geweld (Dekker, 2015). Deze term werd in 1978 geïntroduceerd door Lenore Walker, die stelde dat BWS zou ontstaan doordat geweld zich in een vast patroon herhaalt, een zogenoemde 'Cycle of Violence', welke vervolgens leidt tot aangeleerde hulpeloosheid (Walker, 2009). Deze cyclus bestaat uit drie fasen, waarbij de eerste fase zich kenmerkt door een steeds grotere spanning bij de dader, die zich uiteindelijk uit in de vorm van verbale, emotionele mishandeling. De spanning loopt in deze fase verder op wanneer het slachtoffer zal proberen om escalatie van het conflict te voorkomen. In de tweede 
fase uit de opgebouwde spanning zich daadwerkelijk in fysieke mishandeling. $\mathrm{Na}$ de mishandeling, in de derde fase, toont de dader spijt en probeert zijn partner terug te winnen. Het slachtoffer krijgt opnieuw hoop op verbetering en houdt de relatie in stand. De cyclus herhaalt zich echter keer op keer, zodat dit volgens Walker resulteert in aangeleerde hulpeloosheid bij het slachtoffer, waarbij zij niet meer zal proberen te ontsnappen aan het geweld - ze verkeert immers in de overtuiging de situatie niet te kunnen verbeteren (Russell e.a., 2010).

Deze dichotome benadering - controlerende mannen versus mishandelde vrouwen - blijkt in de empirische werkelijkheid iets genuanceerder te liggen: zo kunnen partnerdodingen ook worden begaan door niet-mishandelende mannen, die niet eerder gewelddadig zijn geweest ten opzichte van hun partner en/of kinderen (Belknap e.a., 2012). Tevens is het niet juist om te stellen, dat vrouwen slechts overgaan tot partnerdoding uit zelfbescherming of ter bescherming van hun kinderen. Net als mannen doden ook vrouwen hun partner uit jaloezie, angst voor verlating, of in de context van een ernstige psychische stoornis (Liem \& Roberts, 2009). Voorts laat onderzoek zien dat (fataal) partnergeweld niet noodzakelijkerwijs louter het gevolg is van patriarchale dominantie of zelfbescherming, maar tevens wederzijds - in situationeel bepaalde context - kan plaatsvinden (Johnson \& Leone, 2005).

\section{Eerder onderzoek}

\subsection{Epidemiologie}

Uit een grootschalige studie naar partnerdoding in achttien westerse landen vonden Stöckl en haar collega's dat vrouwen die om het leven worden gebracht, het grootste risico lopen door hun partner te worden gedood (Stöckl e.a., 2013). In deze landen tezamen blijkt uit hun onderzoek dat één op de zeven levensdelicten een partnerdoding betreft, variërend van ongeveer $15 \%$ tot $20 \%$ van alle levensdelicten. Omdat percentages een weerspiegeling zijn van het aandeel partnerdodingen van het totaal aantal dodingen, zijn ze niet goed vergelijkbaar. Immers, wanneer het totale aantal levensdelicten in een bepaalde periode erg hoog ligt, kan het percentage partnerdodingen relatief laag zijn en omgekeerd kan het percentage stijgen wanneer het totale aantal levensdelicten daalt. Vandaar dat we in internationaal vergelijkend onderzoek vaak gebruikmaken van slachtofferratio's (zie figuur 1 en tabel 1 op p. 38). Hieruit blijkt dat de ratio in Canada aanzienlijk lager ligt dan in de Verenigde Staten. Tevens blijkt het risico op slachtofferschap in Finland flink hoger te liggen dan in andere Scandinavische landen, zoals Denemarken en Zweden.

Eerder Amerikaans onderzoek wijst uit dat de meeste slachtoffers van partnerdodingen vrouwen zijn, met een gemiddelde leeftijd van ongeveer 38 jaar (Smith e.a., 2014). Studies uit Scandinavische landen laten een hogere slachtofferleeftijd zien van 44 jaar in zowel Denemarken (Leth, 2009), Finland (Granath e.a., 2011) als Zweden (Granath e.a., 2011). Eerdere Nederlandse studies lieten een gemiddelde slachtofferleeftijd van 35 jaar zien (Smit \& Nieuwbeerta, 2007). Europees 
Tabel 1 Slachtofferratio in partnerdoding per 100.000 inwoners

\begin{tabular}{|c|c|c|c|c|}
\hline Auteur(s) & $\begin{array}{l}\text { Ratio per } \\
100.000\end{array}$ & $\mathbf{N}$ & Periode & Regio \\
\hline Leth & 0,2 & 36 & $1983-2007$ & Zuid-Denemarken \\
\hline Rying & 0,36 & - & 2001 & Zweden \\
\hline Granath et al. & $0,28^{*}$ & 92 & $2003-2006$ & Zweden \\
\hline Granath et al. & $0,56^{*}$ & 112 & $2003-2006$ & Finland \\
\hline Corradi \& Stöckl & $0,2^{* *}$ & 115 & 2011 & Engeland \& Wales \\
\hline Corradi \& Stöckl & $0,07 * *$ & 56 & 2012 & Duitsland \\
\hline Statistics Canada & 0,24 & - & 2013 & Canada \\
\hline Statistics Canada & 0,28 & - & 2014 & Canada \\
\hline Bureau of Justice Statistics & $0.5 I^{*}$ & 1499 & 2004 & Verenigde Staten \\
\hline Bureau of Justice Statistics & $0.5 I^{*}$ & 1510 & 2005 & Verenigde Staten \\
\hline
\end{tabular}

* De algemene moordratio was bekend; de partnerdodingsratio werd berekend met behulp van de moordratio.

** De partnerdodingsratio werd berekend met behulp van het aantal partnerdodingen $(\mathrm{N})$ en cijfers over de bevolkingsomvang, verkregen door resp. het Centraal Bureau Statistiek, Office for National Statistics en Destatis, Statistisches Bundesamt.

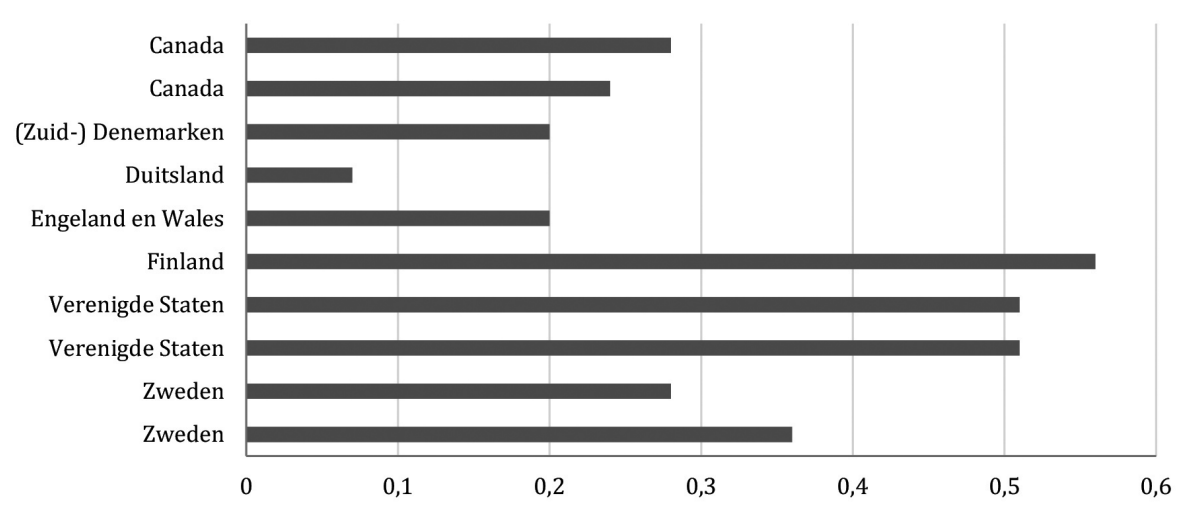

Figuur 1 Slachtofferratio in partnerdoding per 100.000 inwoners

onderzoek wijst tevens uit, dat mannen de grote meerderheid van daders van partnerdoding vormen, met een gemiddelde leeftijd van 45 jaar in Zweden (Granath e.a., 2011) en 44 jaar in Denemarken, evenals in Finland (Granath e.a., 2011).

Naast eerder onderzoek naar epidemiologische factoren, is inmiddels ook veel bekend over de meest prevalente risicofactoren, zoals alcohol, vuurwapens, eerder huiselijk geweld en (dreigen met) het beëindigen van een relatie. Daarnaast heeft eerder Amerikaans onderzoek gewezen naar het toegenomen risico op partnerdoding bij de aanwezigheid van stiefkinderen in het huishouden en gedwongen seks (Campbell e.a., 2003). 
Voorts wijzen eerdere studies uit, dat de beschikking over vuurwapens gepaard gaat met een verhoogd risico om slachtoffer van partnerdoding te worden (Campbell e.a., 2007). Zo blijkt vooral uit Amerikaanse studies dat de grote meerderheid van partnerdodingen wordt gepleegd door middel van een vuurwapen (Smith e.a., 2014; Roberts, 2009; Campbell e.a., 2003). Het is daarom wellicht niet verwonderlijk dat in Amerikaanse risicotaxatie-instrumenten zoals de SARA (Spousal Assault Risk Assessment) en het Danger Assessment (DA) instrument (Campbell e.a., 2007) (vuur)wapens als één van de belangrijkste determinanten wordt gezien voor partnerdoding.

\subsection{Eerder onderzoek in Nederland}

Eerder onderzoek naar partnerdoding in Nederland kan worden onderverdeeld in drie groepen: (a) onderzoek naar partnerdoding als deel van grotere epidemiologische studies naar moord en doodslag, (b) onderzoek naar de onderliggende motieven van partnerdoding en ten derde (c) onderzoek naar de effecten van partnerdoding op kinderen.

In eerder beschrijvend onderzoek naar levensdelicten in Nederland bleek dat er in de jaren negentig ongeveer veertig partnerdodingen per jaar plaatsvonden. Dit aantal bleef relatief constant tot in de eerste jaren van dit millennium (Nieuwbeerta \& Leistra, 2007). Hoewel dergelijk epidemiologisch onderzoek een algemeen beeld kan vormen over de omvang en langetermijntrends van partnerdoding, blijft de mate van gedetailleerdheid zeer beperkt. Zo wordt in dergelijke epidemiologische overzichten niet duidelijk wat de beweegredenen waren van de dader om tot partnerdoding over te gaan.

Een tweede type onderzoek naar partnerdoding richt zich op de onderliggende motieven. Zo bekeek De Boer ongeveer 120 zaken van partnerdoding, die waren onderzocht in het Pieter Baan Centrum (PBC), in de periode 1950-1980. Hij vond drie veelvoorkomende motieven, te weten: passionele motieven (een impulsieve handeling die geschiedt vanuit plotseling oplaaiende emoties door bijvoorbeeld een plotselinge aankondiging te willen scheiden), utilitaire motieven (een weloverwogen doding op grond van het 'profijtbeginsel') en overige motieven. De overige motieven variëren van doding omdat zowel de dader als het slachtoffer psychisch ernstig gestoord is en ze hun problemen niet meer het hoofd kunnen bieden, het toe-eigenen van de kinderen na een scheiding, tot doding begaan vanuit een (paranoïde) waan (De Boer, 1990). Daarnaast bekeken Liem, Geene en Koenraadt (2007) zo'n vierhonderd zaken van verdachten van (pogingen tot) partnerdoding, die eveneens in het $\mathrm{PBC}$ waren onderzocht. In dit onderzoek besteedden ze nader aandacht aan de etnische achtergrond van de verdachten. $\mathrm{Zij}$ vonden dat verdachten met een niet-Nederlandse etnische achtergrond een relatieve oververtegenwoordiging vormden en namen de relatie tussen etnische achtergrond en motieven nader onder de loep. Ondanks dat deze onderzoeken, voornamelijk gebaseerd op informatie uit rapportages pro Justitia, gedetailleerd inzicht bieden in de motieven die ten grondslag liggen aan partnerdoding, kunnen de bevindingen uit beide studies niet zonder meer gegeneraliseerd worden naar de gehele Nederlandse populatie. Immers, diegenen die voor een 
rapportage pro Justitia in het Pieter Baan Centrum werden geobserveerd, verschillen wellicht van diegenen van wie geen rapportage is opgemaakt.

Een derde onderzoekslijn, tot slot, betreft onderzoek door Alisic en collega's (2015) naar de effecten van partnerdoding op kinderen van gedode ouders. Hierbij onderzochten zij de gevolgen voor 257 minderjarige nabestaanden betreffende gezag, plaatsing en omgang met de dader-ouder en de rol van de instanties. Omdat de focus van dit onderzoek op de secundaire slachtoffers van partnerdoding lag in plaats van op de daders en primaire slachtoffers, biedt het beperkt inzicht in de huidige aard en omvang van partnerdoding.

Er bestaat thans geen uniform overzicht van de huidige aard en incidentie van partnerdoding in Nederland. Dit artikel beoogt deze lacune te vullen door zowel inzicht te geven in trendontwikkelingen, alsook een gedetailleerde analyse op zaak-, slachtoffer- en verdachteniveau weer te geven van partnerdoding in Nederland.

\section{Methodologie}

\subsection{Procedure}

Dit onderzoek heeft als doel de aard en omvang van partnerdoding in Nederland voor de periode 2009-2014 inzichtelijk te maken. Er is gekozen voor deze periode van vijf jaar om het onderzoek haalbaar te maken en inzicht te krijgen in zaken die reeds afgerond zijn - recentere zaken bevindingen zich vaak nog in het strafrechtstadium en zijn daarom niet toegankelijk voor extern onderzoek. De data zijn afkomstig uit diverse bronnen, te weten journalistieke bronnen, strafrechtelijke dossiers en politiegegevens.

De jaarlijkse moordlijsten van het Weekblad Elsevier vormen de basis van het epidemiologische deel van dit onderzoek. In deze moordlijsten wordt het totale overzicht van moord (art. 289 en 291 Wetboek van Strafrecht) en doodslag (art. 287, 288 en 290 Wetboek van Strafrecht) in Nederland voor het desbetreffende jaar gegeven. Zaken waarbij sprake was van mishandeling met de dood tot gevolg (art. 302 Wetboek van Strafrecht) zijn in dit onderzoek buiten beschouwing gelaten. Deze lijsten zijn gebaseerd op berichten van het Algemeen Nederlands Persbureau (ANP) en krantenberichten en geven informatie over slachtofferkarakteristieken, relatie tussen dader en slachtoffer en over waar, wanneer en hoe de moord is gepleegd (zie ook: Nieuwbeerta \& Leistra, 2003). Daarnaast zijn online moordlijsten geraadpleegd, waaruit een aantal extra zaken naar voren kwam dat is meegenomen in de analyses. ${ }^{1}$ De informatie uit de moordlijsten van Weekblad Elsevier is als leidend beschouwd wanneer de gegevens in deze bronnen onderling afweken. Voorts zijn er voor elke partnerdodingszaak aanvullende krantenberichten gezocht via de krantendatabank LexisNexis. Zoektermen die hiervoor zijn gebruikt, zijn de pleegdatum, de pleegplaats en trefwoorden als 'dood', 'moord', 'partner', 'echtgenoot', 'man' of 'vrouw'. Zowel ANP-berichten als berichten uit 
nationale en regionale kranten zijn geraadpleegd. Op deze wijze hebben we 173 partnerdodingszaken in de periode 2009-2014 geregistreerd.

Voorts hebben we deze informatie gevalideerd aan de hand van politiegegevens afkomstig uit de Basis Voorziening Handhaving (BVH), ontsloten in COGNOS, het managementinformatiesysteem van de Nederlandse politie. Binnen de BVH worden meldingen geregistreerd, aangiftes verwerkt en incidenten afgehandeld. Met medewerking van het Bureau Management Informatie Nationale Politie werden politiedata omtrent levensdelicten verstrekt met als inclusiecriteria moord, doodslag en zware mishandeling de dood ten gevolge hebbende.

In de derde plaats hebben we deze informatie gevalideerd en aangevuld door middel van analyse van 34 strafrechtelijke dossiers bij zes regionale parketten (Amsterdam, Haarlem, Rotterdam, Noord-Nederland, Noord-Holland en OostBrabant), die we in de eerste paar maanden van 2016 op de parketten hebben ingezien. Deze parketdossiers leverden extra en specifiekere informatie (welke vaak in krantenberichten en in politiedata ontbrak) over het slachtoffer, de verdachte, de locatie, modus operandi enzovoort. Vergeleken met andere delicten, is het zogenoemde dark number onder levensdelicten beperkt, zeker wanneer het - zoals in het geval van partnerdoding - gaat om het doden van een volwassen slachtoffer. Dit gegeven, gecombineerd met het gebruik van diverse bronnen, stelt ons in staat om een compleet en betrouwbaar overzicht te geven van de aard en omvang van dit type delict.

Casussen, die in eerste instantie door moordlijsten van Weekblad Elsevier als potentiële partnerdodingen werden aangemerkt, werden buiten beschouwing gelaten indien er weliswaar een verdachte was, maar vrijspraak volgde, zoals in de casus Edward Mink, waarbij er volgens de rechtbank sprake was van 'te veel redelijke twijfel over de betrokkenheid van de verdachten' (Omroep West, 2015). Daarom spreken we in dit onderzoek van daders in plaats van over verdachten. Tevens zijn zaken uit de selectie verwijderd, wanneer na autopsie onduidelijkheid ontstond omtrent de doodsoorzaak. In dergelijke gevallen oordeelde de rechtbank dat niet kon worden vastgesteld dat het slachtoffer ten gevolge van al dan niet gewelddadig handelen van de verdachte kwam te overlijden. Derhalve zijn deze zaken door ons niet aangemerkt als partnerdodingen. Daarnaast diende een partnerdoding door meerdere bronnen als zodanig te zijn aangemerkt. Indien er maar één krantenartikel was geschreven over een mogelijke partnerdoding en dit krantenartikel niet te valideren was met de politiedata, werd deze zaak niet meegenomen in het onderzoek.

\subsection{Codering}

Vervolgens hebben we de zaak-, slachtoffer- en daderkarakteristieken gecodeerd aan de hand van de European Homicide Monitor, een uniform gevalideerd Europees coderingssysteem voor levensdelicten (Granath e.a., 2011; Liem et al., 2013). Door bijna honderd variabelen en de uniforme manier van coderen door samenwerkende Europese landen maakt dit coderingssysteem gedetailleerde internationale vergelijkingen mogelijk. Voor het coderen van de casussen zijn de strafrechtelijke dossiers en gerechtelijke uitspraken als leidende informatiebron gebruikt, gevolgd door politiedata. Informatie verkregen uit krantenartikelen was 
aanvullend. Indien er geen politiedata, uitspraak of dossier beschikbaar was, was de informatie uit de moordlijsten van Weekblad Elsevier leidend.

Wanneer gesproken wordt over slachtoffers, wordt in het geval van een enkelvoudige partnerdoding (met één slachtoffer) het slachtoffer bedoeld en in het geval van een meervoudige moord (bijvoorbeeld doding van meerdere gezinsleden) wordt het slachtoffer bedoeld met wie de dader een partnerrelatie had. Bij meerdere daders gaan we uit van de dader met wie het slachtoffer een partnerrelatie had. De slachtofferratio per 100.000 inwoners is berekend op basis van de bevolkingsomvang vanaf 16 jaar in Nederland voor de desbetreffende jaren (CBS, 2015a).

Met betrekking tot geografische spreiding van partnerdoding beschouwen we een gebied als stedelijk indien er meer dan 1500 mensen per vierkante kilometer in de gemeente wonen. Als dat niet het geval is, dan is er sprake van een landelijk gebied (CBS, 2016a). Indien er sprake was van meerdere modi operandi, werd de doodsoorzaak gecodeerd als modus operandi. Sinds enkele jaren wordt de etniciteit in officiële documentatie, waaronder strafrechtdossiers en processen-verbaal, niet geregistreerd. Daarom bleef voor een zeer groot deel van de daders en slachtoffers de etniciteit onbekend.

Voorts hebben we één motief per delict gecodeerd, waarbij strafrechtelijke dossiers en gerechtelijke uitspraken de belangrijkste bronnen van informatie waren. Indien deze bronnen niet beschikbaar waren, werden krantenartikelen gebruikt om het belangrijkste motief te achterhalen. Indien de belangrijkste reden van de partnerdoding was dat het slachtoffer volgens de dader 'aan het zeuren' was, dan is dit gecodeerd als 'trivialiteit'. Als het motief een boosheid of een uit de hand gelopen woordenwisseling was, dan is dit gecodeerd als 'overig'. Het motief bleef in gevallen van partnerdoding gevolgd door zelfdoding veelal onbekend. Wanneer een dader geen gevangenisstraf werd opgelegd, maar werd veroordeeld tot tbs, werd het motief 'psychische stoornis' gecodeerd. Als een dader zich bedreigd voelde door het slachtoffer in de situatie voorafgaand aan het delict, dan is gekozen voor het motief 'verdediging tegen partner'.

Aan de hand van beschrijvende statistieken behandelen we achtereenvolgens de zaakkarakteristieken, karakteristieken van het primaire slachtoffer en van de primaire dader.

\section{Resultaten}

\subsection{Zaakkarakteristieken}

In de periode 2009-2014 vonden 173 partnerdodingszaken plaats, waarbij 192 slachtoffers om het leven kwamen en 186 daders betrokken waren. Van alle levensdelicten die in deze tijd plaatsvonden, betrof ongeveer één op de vijf een partnerdoding. Figuur 2 geeft deze cijfers weer en plaatst ze in de context van eerder onderzoek naar levensdelicten in Nederland (Liem et al., 2012; Nieuwbeerta \& Leistra, 2007; Nieuwbeerta \& Leistra, 2003; Smit \& Nieuwbeerta, 2007). 


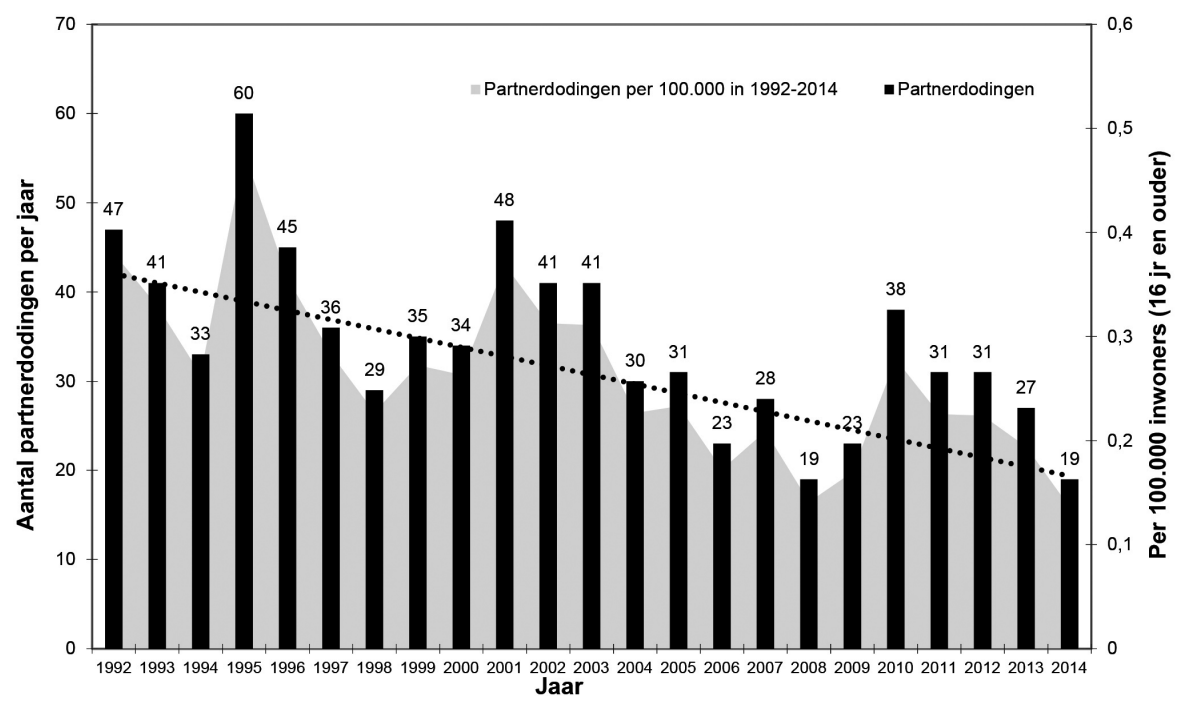

Noot: Voor de periode 1992-2009 zijn de gegevens afkomstig uit Liem, Smit, Van Wilsem \& Nieuwbeerta (2012).

\section{Figuur 2 Aantal en ratio partnerdodingen in Nederland, 1992-2014}

De trend van partnerdodingen in de periode 2009-2014 lijkt - ondanks sterke jaarlijkse fluctuaties - een voortzetting van een kleine daling op langere termijn (zie figuur 2), van ruim 0,3 in het begin van de jaren negentig naar minder dan 0,2 in de vroege jaren tien. Gemiddeld vonden er in de periode 2009-2014 jaarlijks 29 partnerdodingszaken plaats.

Wanneer we nader kijken naar zaakkarakteristieken, laten resultaten zien dat elf partnerdodingszaken meerdere slachtoffers bevatten. Alle meervoudige dodingen werden door mannelijke daders gepleegd. Dit betroffen zeven zaken van familicide, waarin een man zijn (ex-)partner en kind(eren) doodde. In zes van deze gevallen maakte de dader hierna een einde aan zijn eigen leven. Daarnaast waren er vier zaken van meervoudige partnerdoding, waar het naast de partner andere slachtoffers betrof: een politieman $(\mathrm{N}=1)$, zus en moeder van het slachtoffer $(\mathrm{N}=1)$, zus en kinderen $(\mathrm{N}=1)$, en een buurman met wie het slachtoffer een affaire had $(\mathrm{N}=1)$.

Drie op de vijf partnerdodingen vonden in landelijk gebied plaats tegenover twee op de vijf dodingen in stedelijke gebieden. Het merendeel van de slachtoffers werd binnenshuis gedood, dat wil zeggen ofwel in een huis dat dader en slachtoffer deelden, in het huis van de dader, het huis van het slachtoffer, of in een tijdelijk verblijf zoals een vakantiehuis of hotelkamer. Daarnaast kwam ongeveer 7\% van de slachtoffers van partnerdoding om het leven in de publieke ruimte, zoals op de openbare weg, in een park of bos.

Ongeveer $41 \%$ van de slachtoffers werd gedood door middel van een steek- of snijwapen. Andere veelvoorkomende doodsoorzaken waren wurging of verstik- 
Tabel 2 Zaakkarakteristieken van partnerdodingen in Nederland, 2009-2014

\begin{tabular}{|c|c|c|}
\hline & $\mathbf{N}$ & $\%$ \\
\hline \multicolumn{3}{|l|}{ Aantal slachtoffers } \\
\hline I & 162 & 94 \\
\hline$>1$ & 11 & 6 \\
\hline \multicolumn{3}{|l|}{ Aantal verdachten } \\
\hline I & 166 & 96 \\
\hline$>1$ & 7 & 4 \\
\hline \multicolumn{3}{|l|}{ Plaats delict } \\
\hline Woning van verdachte en slachtoffer & 90 & 52 \\
\hline Woning van verdachte & 13 & 8 \\
\hline Woning van slachtoffer & 42 & 24 \\
\hline Park, bos of recreatiegebied & 5 & 3 \\
\hline $\begin{array}{l}\text { Publieke weg, openbaar vervoer of andere openbare } \\
\text { plek }\end{array}$ & 7 & 4 \\
\hline Overig & 15 & 9 \\
\hline Onbekend & 1 & - \\
\hline \multicolumn{3}{|l|}{ Geografische regio } \\
\hline Stedelijk gebied & 70 & 40 \\
\hline Landelijk gebied & 103 & 60 \\
\hline \multicolumn{3}{|l|}{ Modus operandi } \\
\hline Vuurwapen & 22 & 15 \\
\hline Snij/steekwapen & 65 & 41 \\
\hline Slagwapen & II & 7 \\
\hline Wurging/verstikking & 44 & 28 \\
\hline Brand & 5 & 3 \\
\hline Overig & 10 & 6 \\
\hline Onbekend & 16 & - \\
\hline
\end{tabular}

king (28\%) en een vuurwapen (15\%). Overige noemenswaardige modi operandi betroffen slagwapens of het in brand steken van het slachtoffer.

\subsection{Karakteristieken van slachtoffers}

In tegenstelling tot andere vormen van geweld en crimineel gedrag, waarin mannen de voornaamste daders en slachtoffers zijn, betreft partnerdoding veelal een mannelijke dader en een vrouwelijk slachtoffer: $82 \%$ van de slachtoffers is vrouw. Dit impliceert dat vrouwen boven de 18 jaar een risico lopen van 2,08 per 100.000 om het slachtoffer te worden van een partnerdoding, vergeleken met een risico van 0,48 per 100.000 voor mannen boven de 18 jaar. De gemiddelde leeftijd van mannelijke slachtoffers van partnerdoding is 48 jaar, vergeleken met 40 jaar 
Tabel 3 Slachtofferkarakteristieken van partnerdodingen in Nederland, 2009-2014

\begin{tabular}{lll}
\hline & N & $\%$ \\
\hline Geslacht & & \\
Vrouw & 142 & 82 \\
Man & 31 & 18 \\
Leeftijd & & \\
$<18$ jaar & 2 & 1 \\
$18-24$ jaar & 28 & 16 \\
$25-34$ jaar & 29 & 17 \\
$35-44$ jaar & 47 & 27 \\
$45-54$ jaar & 33 & 19 \\
$55-64$ jaar & 18 & 11 \\
$\geq 65$ jaar & 16 & 9 \\
\hline
\end{tabular}

voor vrouwelijke slachtoffers. Veruit de meeste vrouwelijke slachtoffers bevinden zich in de leeftijdscategorieën van 18 tot 24 jaar en van 35 tot 44 jaar, waarin ze tevens het hoogste risico lopen om door hun partner gedood te worden: 3,48 per 100.000. Het risico op slachtofferschap is het laagst voor vrouwen boven de 65 jaar (0,73 per 100.000), gevolgd door vrouwen tussen de 55 en 64 jaar $(0,83$ per 100.000). Vrouwen tussen de 25 en 34 jaar lopen een gemiddeld risico van 2,39 per 100.000 om slachtoffer te worden, vergelijkbaar met vrouwen tussen de 45 en 54 jaar, die een risico lopen van 2,40 per 100.000 .

\subsection{Karakteristieken van daders}

De meeste daders van partnerdoding betroffen mannen (86\%), die hun vrouwelijke (ex-) partner doodden. Mannen van 18 jaar en ouder lopen daarmee een risico van 2,29 per 100.000 om als dader bij een partnerdoding betrokken te raken, vergeleken met 0,36 per 100.000 voor vrouwen. Mannen zijn over het algemeen iets ouder dan vrouwen: mannelijke daders zijn gemiddeld 43, vrouwelijke daders 40 jaar oud. Het risico om als dader betrokken te zijn bij een partnerdoding is het grootst in de leeftijdscategorie 45-54 jaar, waarbij mannen een risico hebben van 3,45 per 100.000. Mannen uit de leeftijdscategorie 25-34 jaar volgen met 3,06 per 100.000 . Het risico om als dader betrokken te raken bij een partnerdoding is het laagst onder diegenen boven de 65 jaar (0,91 per 100.000) en in de leeftijdscategorie 55-64 jaar (1,65 per 100.000). De leeftijdscategorieën 18-24 jaar (1,76 per 100.000) en 35-44 jaar (2,54 per 100.000) nemen een tussenpositie in.

Verreweg de meeste partnerdodingen vonden plaats binnen heteroseksuele koppels (96\%), waarbij (ex-)vrouwen (37\%) en (ex-)vriendinnen (42\%) van de dader het vaakst slachtoffer werden. Wanneer we onderscheid maken tussen bestaande en voormalige relaties, laten de resultaten zien dat in twee derde (68\%) van de 
gevallen het slachtoffer een relatie met de dader had, terwijl in een derde (30\%) van de partnerdodingen de relatie reeds was beëindigd. In $2 \%$ van de zaken was de status quo van de relatie onbekend. In ongeveer één op de vijf zaken ging de dader over tot (een poging tot) zelfdoding. Het motief voor de partnerdoding blijkt veelal angst voor verlating door het slachtoffer, gevolgd door het beschouwen van het slachtoffer als 'eigendom'. Wanneer het slachtoffer de dader wil verlaten, past hij fataal geweld toe in een ultieme poging het slachtoffer aan hem te binden. In ongeveer een kwart van de zaken was er sprake van alcoholgebruik door de dader. In verreweg de meeste gevallen werd er bij de dader een gevangenisstraf opgelegd (61\%), al dan niet in combinatie met tbs (16\%). Afgezien van twee levenslange gevangenisstraffen was de gemiddelde lengte van de opgelegde straf tien jaar. In de 31 gevallen van zelfdoding van de dader werd logischerwijs geen sanctie opgelegd.

Tabel 4 Karakteristieken van verdachten van partnerdodingen in Nederland, 2009-2014

\begin{tabular}{|c|c|c|}
\hline & $\mathbf{N}$ & $\%$ \\
\hline \multicolumn{3}{|l|}{ Geslacht } \\
\hline Man & 149 & 86 \\
\hline Vrouw & 24 & 14 \\
\hline \multicolumn{3}{|l|}{ Leeftijd } \\
\hline$<18$ jaar & 0 & 0 \\
\hline I8-24 jaar & 16 & 9 \\
\hline 25-34 jaar & 35 & 21 \\
\hline 35-44 jaar & 37 & 22 \\
\hline 45-54 jaar & 51 & 30 \\
\hline 55-64 jaar & 21 & 12 \\
\hline$<65$ jaar & II & 6 \\
\hline Onbekend & 2 & - \\
\hline \multicolumn{3}{|c|}{ Geslacht verdachte-slachtoffer } \\
\hline Man-vrouw & 142 & 82 \\
\hline Vrouw-man & 24 & 14 \\
\hline Man-man & 7 & 4 \\
\hline Vrouw-vrouw & 0 & 0 \\
\hline \multicolumn{3}{|c|}{ Relatie slachtoffer-verdachte } \\
\hline Man & 8 & 5 \\
\hline Ex-man & 1 & 1 \\
\hline Vriend & 16 & 9 \\
\hline Ex-vriend & 5 & 3 \\
\hline Vrouw & 51 & 29 \\
\hline Ex-vrouw & 16 & 9 \\
\hline Vriendin & 44 & 25 \\
\hline
\end{tabular}


Tabel 4 (Vervolg)

\begin{tabular}{|c|c|c|}
\hline & $\mathbf{N}$ & $\%$ \\
\hline Ex-vriendin & 30 & 17 \\
\hline Prostituee (voormalig of huidig) & I & I \\
\hline Mannelijke (ex-)partners, status onbekend & 1 & I \\
\hline \multicolumn{3}{|l|}{ Suïcide } \\
\hline Suïcide & 31 & 18 \\
\hline Suïcidepoging & 19 & II \\
\hline Geen suïcide / suïcidepoging & 123 & 71 \\
\hline \multicolumn{3}{|l|}{ Motief } \\
\hline Partner als eigendom (wraak en jaloezie) & 20 & 17 \\
\hline Angst voor verlating & 38 & 33 \\
\hline Verdediging tegen partner & 6 & 5 \\
\hline Psychische stoornis & 11 & 9 \\
\hline Trivialiteit & 7 & 6 \\
\hline Overig & 35 & 30 \\
\hline Onbekend & 56 & - \\
\hline \multicolumn{3}{|l|}{ Alcoholgebruik voorafgaand aan delict } \\
\hline Geen indicatie alcoholgebruik & 108 & 76 \\
\hline Enige indicatie voor alcoholgebruik & 14 & 10 \\
\hline Sterke indicatie voor alcoholgebruik & 20 & 14 \\
\hline Onbekend & 31 & - \\
\hline \multicolumn{3}{|l|}{ Gerechtelijke sanctie } \\
\hline Geen sanctie & 31 & 19 \\
\hline Detentie & 100 & 61 \\
\hline Tbs & 6 & 4 \\
\hline Detentie en tbs & 27 & 16 \\
\hline Onbekend & 9 & - \\
\hline
\end{tabular}

\section{Discussie}

\subsection{Bevindingen}

In dit onderzoek hebben we getracht antwoord te geven op de vraag in hoeverre partnerdodingen aan eenzelfde daling onderhevig zijn als andere typen levensdelicten. Daarnaast hebben we inzicht gegeven in de zaak-, slachtoffer- en daderkarakteristieken van dit unieke type doding. Overeenkomstig eerder onderzoek in andere West-Europese landen worden veruit de meeste partnerdodingen binnenshuis gepleegd en gaat het om een mannelijke dader en een vrouwelijk slachtoffer, waarbij de doding voortkomt uit jaloezie, wraak en angst om door het slachtoffer verlaten te worden (Caman e.a., 2016; Kivisto, 2015). Ondanks sterke jaarlijkse schommelingen lijkt partnerdoding in Nederland op de lange termijn te dalen. 
Waar in het begin van de jaren negentig ongeveer 0,3 partnerdodingsslachtoffers per 100.000 vielen, daalde dit cijfer in de afgelopen jaren gestaag naar 0,2 partnerdoding slachtoffers per 100.000. Hiermee neemt Nederland vergeleken met andere westerse landen een lage positie in, vergelijkbaar met Denemarken (Leth, 2009) en Engeland \& Wales (Corradi \& Stöckl, 2014).

Het aantal slachtoffers van partnerdoding is dus zowel absoluut als relatief (naar het aantal inwoners) sterk gedaald. Deze trend lijkt te passen in een langetermijntrend van een lichte daling in partnerdodingen. Enerzijds zou men deze daling kunnen interpreteren als een onderdeel van de algemene daling in levensdelicten in Nederland en in het verlengde daarvan als een voortzetting van de al enige eeuwen durende daling van geweldscriminaliteit. De daling in partnerdodingen zou aldus, vanuit dit perspectief, tevens door Elias' (1978) civilisatietheorie zijn te verklaren. Deze aanname loopt echter mank wanneer we op individueel niveau kijken naar de motieven die ten grondslag liggen aan partnerdoding, waaronder jaloezie, angst voor verlating en het gebruik van dodelijk geweld uit zelfbescherming. Dergelijke motieven zien we niet terug onder 'typische' moorden buiten gezinsverband. Ten slotte zien we tevens dat hoewel de ratio partnerdodingen een lichte daling laat zien in de afgelopen jaren, deze daling niet zo sterk is als de algehele daling in levensdelicten (Liem e.a., 2012), wat suggereert dat de trend van partnerdoding aan andere factoren onderhevig is dan andere dodingen. Deze bevindingen lijken daarentegen voorzichtige steun te vinden voor Verkko's wetten: waar het algemene moordcijfer in deze periode relatief sterk daalde (van 1,57 in de jaren negentig tot 0,94 in de afgelopen jaren) (Liem \& Leissner, 2016), daalde het partnerdodingscijfer slechts beperkt (met ongeveer 0,1 per 100.000). Dit bevestigt het beeld dat is geschetst door Verkko (1951), dat fluctuaties in het moordcijfer met name zijn toe te schrijven aan een daling in man-tot-manmoorden (Lehti \& Kivivuori, 2012).

Een andere verklaring die vaak geboden wordt voor de schommeling in moordcijfers is de mate van werkloosheid. In een studie op basis van moordcijfers uit 1992-2009 hebben Liem, Van Wilsem, Smit en Nieuwbeerta (2012) getracht de Nederlandse daling in levensdelicten te verklaren door te kijken naar onder andere het werkloosheidscijfer. De resultaten boden een voorzichtige steun voor het economische deprivatie-perspectief. Werkloosheid kan leiden tot frustratie en agressie, die in het meest extreme geval kunnen uitmonden in een levensdelict. Er valt te speculeren dat deze factor ook deels van toepassing is op partnerdodingen in Nederland. Immers, na 2008 steeg de werkloosheid fors, van 3,7\% tot 7,4\% in 2014 (CBS, 2016b). Partnerdodingen in deze periode, zo laten onze resultaten zien, vertoonden in 2009, 2010 en 2011 een stijging. Het strekt tot aanbeveling om in toekomstig onderzoek nader aandacht te besteden aan financiële stressoren in zaken van partnerdoding, met name stressoren voortkomend uit (langdurige) werkloosheid, om te onderzoeken in hoeverre er een causaal verband bestaat tussen economische crises en (fataal) partnergeweld.

Een derde verklaring is mogelijk te vinden in de verminderde mate waarin vrouwen worden blootgesteld aan gewelddadige relaties. Volgens de eerder besproken patriarchale theorie zouden een lagere huwelijksratio, een toename in echtscheidingen, toegenomen financiële onafhankelijkheid voor vrouwen en toegenomen 
beschikbaarheid van hulp bij huiselijk geweld, resulteren in een lagere partnerdodingsratio. Immers, vrouwen hebben door deze ontwikkelingen eerder de mogelijkheid een einde te maken aan een gewelddadige relatie, waardoor het aantal partnerdodingen zowel door mannen (als extreme vorm van huiselijk geweld) als door vrouwen (uit zelfbescherming) zou dalen. Deze hypothese heeft eerder steun gekregen in Amerikaans onderzoek naar de daling van partnerdodingen (Dugan e.a., 2009). Wanneer we deze hypothese op de Nederlandse situatie toepassen, kunnen we de volgende trends observeren. In de periode 1992-2014 daalde het relatieve aantal huwelijkssluitingen geleidelijk van 6,2 naar 3,8 per 100.000 inwoners (CBS, 2015b). In dezelfde periode steeg het echtscheidingspercentage gestaag van $29,3 \%$ tot 40,1\% (CBS, 2015c). Deze trend kan een deel van de verklaring voor de daling in partnerdodingen vormen, hoewel de daling scherper lijkt te zijn dan de mate waarin gescheiden wordt en minder getrouwd wordt. Hierbij dient opgemerkt te worden dat op individueel niveau (dreiging met) echtscheiding een veelvuldig genoemde aanleiding tot partnerdoding vormt. Dit effect staat ook wel bekend als het 'backlash effect': met een verandering in man-vrouwmachtsverhoudingen, toegenomen zelfstandigheid voor vrouwen en de mogelijkheid tot scheiden, ontstaat er theoretisch gezien meer kans op (fataal) geweld, in een ultieme poging van de (mannelijke) dader om de machtsverhoudingen te herstellen (Reckdenwald en Parker, 2012; Vieraitis en Williams, 2002). Hoewel in Nederland grote stappen zijn gezet met het (h)erkennen van huiselijk geweld is blijvende alertheid op casusniveau geboden, met name in het kader van een (op handen zijnde) scheiding. Door specifieke training van politiepersoneel, nauwe samenwerking binnen ketenpartners (Corradi \& Stöckl, 2014) en het gebruik van gevalideerde risicotaxatie-instrumenten kunnen dergelijke dynamieken vroegtijdig worden gesignaleerd.

Omgekeerd kan ook gesteld worden, dat toegenomen zelfstandigheid er juist toe leidt dat men escalatie eerder voorkomt, doordat de mogelijkheid tot scheiden er is. Men is immers dan niet meer veroordeeld om eeuwig bij elkaar te blijven. Aangezien in de bestudeerde periode in Nederland het echtscheidingspercentage toenam, terwijl de partnerdodingsratio juist afnam, lijken onze bevindingen op macroniveau geen steun te geven aan het 'backlash-effect', maar eerder voorzichtig te wijzen op de mogelijk positieve invloed die de beschikbaarheid van echtscheidingen kan hebben op de daling.

Een vierde factor die kan bijdragen aan het verklaren van de daling van partnerdoding is het inkomensverschil tussen mannen en vrouwen. Gemeten vanaf het begin van deze eeuw is er niet veel veranderd: vrouwen met een voltijdbaan verdienen ruim $80 \%$ van wat mannen gemiddeld verdienen (CBS, 2015d). Dat lijkt daarom geen sluitende verklaring te bieden. Andere verklaringen zouden kunnen liggen in een toename van hulpverlening op het gebied van huiselijk geweld. Wanneer we echter kijken naar de beschikbaarheid van vrouwenopvang, laten recent bijgehouden CBS-cijfers zien dat het aantal zorginstellingen voor maatschappelijke opvang, waaronder vrouwenopvang, juist is gedaald, van 48 in 2007 naar 35 ondernemingen in 2014 (CBS, 2015e). Tot slot blijkt dat het aantal meldingen van huiselijk geweld de laatste jaren sterk is gestegen, terwijl er geen aanwijzingen zijn dat deze problematiek steeds vaker voorkomt. Er blijkt dus een hogere 
aangiftebereidheid te zijn onder vrouwen. Het CBS en het SCP (2014) concludeerden in hun rapport voorzichtig dat deze bereidheid mogelijk toe te schrijven is aan een hogere alertheid van en betere samenwerking tussen opsporings- en hulpverlenende instanties. Er lijken daarom geen aanwijzingen voor een sterke ondersteuning van de eerder besproken zelfverdedigingshypothese. Immers, men zou verwachten dat met een afname in hulpverleningsinstanties en een gelijkblijvende prevalentie van huiselijk geweld, meer vrouwen uit zelfverdediging overgaan tot partnerdoding. De data lijken dit echter niet te ondersteunen. Partnerdoding door vrouwen komt over de gehele periode bezien relatief weinig voor.

$\mathrm{Bij}$ het interpreteren van deze resultaten aan de hand van deze hypothesen is terughoudendheid echter geboden te worden. Partnerdoding blijft nog steeds een relatief zeldzaam fenomeen, waardoor schommelingen in enkele aantallen per jaar op het eerste gezicht aanzienlijk lijken, terwijl bij nadere bestudering het nog steeds om relatief kleine aantallen gaat.

\subsection{Methodologische tekortkomingen}

Hoewel we door het koppelen van data uit diverse bestanden in staat zijn geweest een nagenoeg compleet overzicht te geven van partnerdoding in Nederland, kent deze aanpak tevens een aantal tekortkomingen. In de eerste plaats zijn mogelijke partnerdodingen niet geïncludeerd, die op het moment van coderen onopgelost waren. Immers, als er geen verdachte is, is het ook niet vast te stellen om welk type doding het gaat. Omgekeerd kunnen er zaken in ons overzicht zijn opgenomen die thans als partnerdoding zijn gecodeerd, maar later een ander type doding blijken te zijn wanneer de huidige (partner)verdachte (in hoger beroep) wordt vrijgesproken en een andere verdachte wordt aangehouden. Voorts boden - wanneer processen-verbaal en strafrechtelijke dossiers niet beschikbaar waren - de summiere nieuwsberichten en de kwantitatieve politiegegevens zelden informatie over een eventuele voorgeschiedenis van huiselijk geweld. Eén manier om beter zicht te krijgen op de aard, incidentie en karakteristieken van deze dodingen is door deze door eenzelfde organisatie structureel te laten observeren en registreren, zoals reeds gedaan wordt in andere landen, zoals Canada (Canadian Femicide Observatory), Mexico (National Observatory against Femicides) en Portugal (Observatório de Mulheres Assassinadas).

Daarnaast zou een kwalitatieve studie, mogelijk in combinatie met een studie naar overlevenden van partnergeweld, inzicht kunnen geven in de rol van huiselijk geweld bij partnerdodingszaken in Nederland en zicht kunnen bieden op manieren van vroegtijdig interveniëren en aan de hand van welke specifieke waarschuwingssignalen dat interveniëren dan zou moeten gebeuren.

\section{Literatuur}

Aebi, M.F. \& A. Linde (2014) The persistence of lifestyles: Rates and correlates of homicide in Western Europe from 1960 to 2010. European Journal of Criminology, 11(5), 552-577. 
Alisic, E., A. Groot, H. Snetselaar, T. Stroeken \& E. van de Putte (2015) Parental intimate partner homicide and its consequences for children: protocol for a population-based study. BMC Psychiatry, 15(177), 1-7.

Bailey, J.E., A.L. Kellermann, G.W. Somes, J.G. Banton, F.P. Rivara \& N.P. Rushforth (1997) Risk factors for violent death of women in the home. Archives of Internal Medicine, 157(7), 777-782.

Belknap, J., D.L. Larson, M.L. Abrams, C. Garcia \& K. Anderson-Block (2012) Types of intimate partner homicides committed by women self-defense, proxy/retaliation, and sexual proprietariness. Homicide Studies, 16(4), 359-379.

Block, C.R. \& A. Christakos (1995) Intimate partner homicide in Chicago over 29 years. Crime \& Delinquency, 41(4), 496-526.

Boer, A.P. de (1990) Partnerdoding. Een empirisch forensisch-psychiatrisch onderzoek. Arnhem: Gouda Quint.

Breiding, M.J., K.C. Basile, S.G. Smith, M.C. Black \& R.M. Mahendra (2015) Intimate Partner Violence Surveillance: Uniform Definitions and Recommended Data Elements. Georgia: Centers for Disease Control and Prevention National Center for Injury Prevention and Control.

Caman, S., K. Howner, M. Kristiansson \& J. Sturup (2016) Differentiating Intimate Partner Homicide From Other Homicide: A Swedish Population-Based Study of Perpetrator, Victim, and Incident Characteristics. Psychology of Violence, 7(2), 306-315.

Campbell, J.C., N. Glass, P.W. Sharps, K. Laughon \& T. Bloom (2007) Intimate Partner Homicide. Review and Implications of Research and Policy. Trauma, Violence, \& Abuse, 8(3), 246-269.

Campbell, J.C., D. Webster, J. Koziol-McLain, C. Block, D. Campbell, M.A. Curry, F. Gary, N. Glass, J. McFarlane, C. Sachs, P. Sharps, Y. Ulrich, S.A. Wilt, J. Manganello, X. Xu, J. Schollenberger, V. Frye \& K. Laughon (2003) Risk Factors for Femicide in Abusive Relationships: Results From a Multisite Case Control Study. American Journal of Public Health, 93(7), 1089-1097.

Centraal Bureau voor de Statistiek (2015a) Bevolking; kerncijfers. Geraadpleegd 18 juli 2016 via www.cbs.nl.

Centraal Bureau voor de Statistiek (2015b) Huwen en partnerschapsregistraties; kerncijfers. Geraadpleegd 1 juli 2016 via www.cbs.nl.

Centraal Bureau voor de Statistiek (2015c) Huwelijksontbindingen; door echtscheiding en door overlijden. Geraadpleegd 1 juli 2016 via www.cbs.nl.

Centraal Bureau voor de Statistiek (2015d) Inkomensongelijkheid; personen in particuliere huishoudens naar kenmerken. Geraadpleegd 1 juli 2016 via www.cbs.nl.

Centraal Bureau voor de Statistiek (2015e) Zorginstellingen; financiële kengetallen. Geraadpleegd 1 juli 2016 via www.cbs.nl.

Centraal Bureau voor de Statistiek (2016a) Begrippen. Geraadpleegd 21 juli 2016 via www. cbs.nl.

Centraal Bureau voor Statistiek (2016b) Arbeidsdeelname kerncijfers. Geraadpleegd 1 juli 2016 via www.cbs.nl.

Corradi, C. \& H. Stöckl (2014) Intimate partner homicide in 10 European countries: Statistical data and policy development in a cross-national perspective. European Journal of Criminology, 11(5), 601-618.

Daly, M. \& M. Wilson (1988) Homicide. New York: Aldine de Gruyter.

Dekker, G. (2015) Battered Woman Syndrome: Syndroom of Subcategorie van PTSS?. Amsterdam: Universiteit van Amsterdam. 
Dugan, L., D.S. Nagin \& R. Rosenfeld (1999) Explaining the Decline in Intimate Partner Homicide The Effects of Changing Domesticity, Women's Status, and Domestic Violence Resources. Homicide Studies, 3(3), 187-214.

Eisner, M. (2003) Long-term historical trends in violent crime. Crime \& Justice, 30, 83-142. Elias, N. (1978) The Civilizing Process (Volumes 1\&2). Oxford: Oxford University Press.

Garcia, L., C. Soria \& E.L. Hurwitz (2007) Homicides and Intimate Partner Violence. A Literature Review. Trauma, Violence, \& Abuse, 8(4), 370-383.

Goussinsky, R. \& D. Yassour-Borochowitz (2012) I killed her, but I never laid a finger on her. A phenomenological difference between wife-killing and wife-battering. Aggression and Violent Behavior, 17, 553-564.

Granath, S., J. Hagstedt, J. Kivivuori, M. Lehti, S. Ganpat, M. Liem \& P. Nieuwbeerta (2011) Homicide in Finland, the Netherlands and Sweden. Stockholm: Bra.

Johnson, M.P. \& J.M. Leone (2005) The differential effects of intimate terrorism and situational couple violence: Findings from the National Violence Against Women Survey. Journal of family issues, 26(3), 322-349.

Kivisto, A.J. (2015) Male perpetrators of intimate partner homicide: a review and proposed typology. Journal of the American Academy of Psychiatry and the Law Online, 43(3), 300-312.

Lehti, M. \& J. Kivivuori (2012) Homicide in Finland. In: M. Liem \& W. Pridemore (eds.), Handbook of European Homicide Research. New York: Springer, 391-404.

Leth, P.M. (2009) Intimate partner homicide. Forensic Science, Medicine, and Pathology, 5(3), 199-203.

Liem, M., K. Geene en F.A.M.M. Koenraadt (2007) Partnerdoding door etnische minderheden. Amsterdam: Dutch University Press.

Liem, M. \& D.W. Roberts (2009) Intimate partner homicide by presence or absence of a self-destructive act. Homicide Studies, 13(4), 339-354.

Liem, M., J.A. van Wilsem, P. Smit \& P. Nieuwbeerta (2012) De daling van moord en doodslag in Nederland. Tijdschrift voor Criminologie, 54(1), 18-34.

Nieuwbeerta, P. \& G. Leistra (2003) Moord en doodslag in Nederland. Een overzicht van alle zaken in de periode 1992-2001. Tijdschrift voor Veiligheid en Veiligheidszorg, 2(3), 36-54.

Nieuwbeerta, P. \& G. Leistra (2007) Dodelijk geweld. Moord en doodslag in Nederland. Amsterdam: Uitgeverij Balans.

Omroep West (18 december 2015) Vrijspraak voor verdachten moord op Edward Mink. Geraadpleegd via www.omroepwest.nl/nieuws/3016119/Vrijspraak-voor-verdachtenmoord-op-Edward-Mink.

Reckdenwald, A. \& K.F. Parker (2012) Understanding the Change in Male and Female Intimate Partner Homicide Over Time A Policy- and Theory-Relevant Investigation. Feminist Criminology, 7(3), 167-195.

Roberts, D.W. (2009) Intimate Partner Homicide. Relationships to Alcohol and Firearms. Journal of Contemporary Criminal Justice, 25(1), 67-88.

Russell, B.L., L. Ragatz \& S.W. Kraus (2010) Self-defense and legal decision making: The role of defendant and victim gender and gender-neutral expert testimony of the battered partner's syndrome. Partner Abuse, 1(4), 399-419.

Serrana, G. \& P. Firestone (2004) Intimate partner homicide: a review of the male proprietariness and the self-defense theories. Aggression and Violent Behavior, 9(1), 1-15.

Smit, P.R. \& P. Nieuwbeerta (2007) Moord en doodslag in Nederland. 1998 en 2002-2004. Den Haag: WODC. 
Smith, S.G., K.A. Fowler \& P.H. Niolon (2014) Intimate Partner Homicide and Corollary Victims in 16 States: National Violent Death Reporting System, 2003-2009. American Journal of Public Health, 104(3), 461-466.

Sociaal en Cultureel Planbureau en Centraal Bureau voor de Statistiek (2014) Emancipatiemonitor 2014. Den Haag: Sociaal en Cultureel Planbureau.

Spierenburg, P.C. (2008) A history of murder: Personal violence in Europe from the middle ages to the present. Cambridge: Polity.

Stöckl, H., K. Devries, A. Rotstein, N. Abrahams, J. Campbell, C. Watts \& C.G. Moreno (2013) The global prevalence of intimate partner homicide: a systematic review. The Lancet, 382(9895), 859-865.

Swatt, M.L. \& N. He (2006) Exploring the Difference Between Male and Female Intimate Partner Homicides. Homicide Studies, 10(4), 279-292.

Tracy, S.R. (2007) Patriarchy and domestic violence: Challenging common misconceptions. Journal of the Evangelical and Theological Society, 50, 573-94.

Verkko, V. (1951) Homicides and suicides in Finland and their dependence on national character. Kopenhagen: G.F.C. Gads Forlag.

Vieraitis, L.M. \& M.R. Williams (2002) Assessing the impact of gender inequality on female homicide victimization across U.S. cities: A racially disaggregated analysis. Violence Against Women, 8, 35-63.

Walker, L.E.A. (2009) The battered woman syndrome. New York: Springer Publishing Company.

Weerman, F.M., J.W. de Keijser \& W. Huisman (2011) Over dalende criminaliteitscijfers en speculerende criminologen. Delikt en Delinkwent, 41, 64-73. 